\title{
An Overview of Export Performance of Agricultural Products in India
}

\author{
Dr.M.Lakshmi Bala ${ }^{1}$, K.Sudhakar ${ }^{2}$ \\ ${ }^{1}$ Head, Department of Business Administration, Kunthavai Nachiyar Govt. Arts College of women, Thanjavur. \\ ${ }^{2}$ Assistant professor, Department of Management studies, Kings College of Engineering, Punakulam, \\ Pudukootai.
}

\begin{abstract}
Exports are the basis of the overall growth performance of any country. By increasing the rate of exports, any developing country can pave a way for the development by earning international liquidity thereby; sort out the problem of reserves to start up of any project to come out the circle of poverty. So, it becomes a paramount importance for the country like India to start export promotion measures to boost up the pace of its exports and India has already taken many steps to increase the level of its exports. It is concluded from the results of the study that Cotton raw including waste, iron ore, plastic and linoleum and transport equipment has been observed as the products in which exports have been increased at the maximum rate, whereas exports of Tea, Iron and steel, Mica and Leather and Manufacturing have been identified as the area in which satisfied results have not been achieved. So, it is suggested by the results of study that government should promote exports of different sectors by providing different incentives to different sectors to avail the opportunity and fill up the gaps as well. Indian agricultural export has undergone significant changes during recent times. In this context, the present study has analysed the trend in exports of agricultural commodities from India, the changes in the comparative advantage, the Indian agricultural export scenario has witnessed during the past decade and the prospects for further boosting the agricultural export. The study has also analysed the comparative advantage of India's exports, through revealed comparative advantage (RCA). The RCA was improving in case of cotton, maize, and certain fruits and vegetables over time, but declining in case of some spices, rice and wheat. In case of plantation based spices and other commodities, India is gradually losing its comparative edge, mainly to Asian countries. The study has so identified yield improvement through growth in total factor productivity (TFP) as a potential factor that would result in generation of exportable surpluses and boosting India's export.
\end{abstract}

\section{Introduction}

Performance of agricultural export has always attracted policy makers' attention, as it is an important source of foreign exchange earnings, driver of crop diversification and farm income improvements. The coming into force of the World Trade Organisation (WTO) has brought a qualitative change in the deliberations on the topic. The domestic preparedness to deal with a globalised and interconnected world, with increased concern on intellectual properties, food safety and quality aspects and international movements of finances and services on the one hand, and domestic livelihood and food security concerns on the other hand, has generated substantial debate. One concern that ran through all the arguments was the ability of the domestic agriculture to cope up with demands of the new paradigm of international monitoring and regulations. Two decades have passed since the WTO came into existence. During this span of time, some of the initial apprehensions have dissipated. However, a different set of problems, notably faster transmission of international price volatility to domestic markets, higher rates of rejection on account of sanitary and phyto-sanitary (SPS) measures, and restriction in providing subsidy supports have emerged. During the past two decades, the domestic agricultural sector has also witnessed several changes, including the composition of public and private investments in agricultural research with greater participation of private sector, emergence of new institutional innovations like contract farming and farmer producer companies, change in the composition of the demand for agricultural commodities in the domestic market, and diversification towards high value crops which has led to differential growth experience for different commodity groups. Accordingly, the focus of agricultural output is also undergoing a paradigm shift.

The competition that a country offers in the international markets for its export depends on a number of factors. A country whose domestic consumption is low and volume of exports is high in terms of share in world exports would be able to provide stiff competition in international markets (Bhattacharya 2002). One major factor that affects the export prospects is the ability of the country to generate exportable surpluses (Singh and Sain 2003) which is dynamic during a period of time and bound to undergo shifts, depending on the macroeconomic changes 


\section{Analytical approach for measuring the export performance:}

Compound growth Rate of different export products has been worked out by fitting exponential function. Using the least square method, the following form of exponential function has been used to calculate Compound Growth Rate.

$\mathrm{Y}=\mathrm{AB}$

$\mathrm{Y}=\mathrm{AB} \mathrm{B}^{\mathrm{t}}$

Where, Y=Export

$\mathrm{A}=$ Constant

$\mathrm{B}=1+\mathrm{r}$

$\mathrm{R}=$ Compound growth rate

$\mathrm{t}=$ time variable in years $(1,2------15)$

The compound growth rate (r) is equal to (B-1) x 100. In log form B has been calculated by the following formula:

$$
\log \mathrm{B}=\frac{\Sigma \mathrm{T} \log \mathrm{Y}-\Sigma \mathrm{t} \Sigma \log \mathrm{Y} / \mathrm{N}}{\Sigma \mathrm{t}^{2}-(\Sigma \mathrm{t})^{2} / \mathrm{N}}
$$

The compound growth rate (r) is equal to (B-1) $x$ 100. In $\log$ form $B$ has been calculated by the following formula

$$
\text { S.E. }(r)=\frac{100 \mathrm{~B}}{\log _{10} \mathrm{e}}
$$

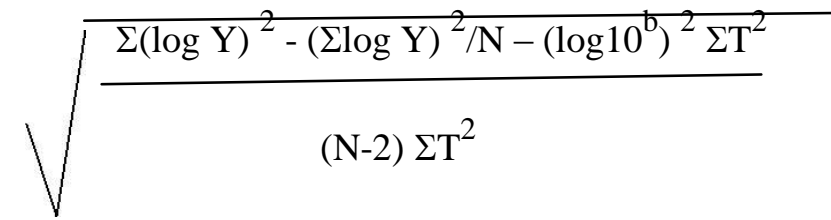

Where $\mathrm{T}=\mathrm{t}-\mathrm{t}$

\section{Change in composition of India's agricultural export}

During the period under analysis, the exports of all commodity groups have registered an increase in value terms. However, there was a change in the composition of export characterised by an increase in the share of meat (and meat products), cereals, spices, sugar, oilseeds, cotton and guargum and a decline in the share of the fish (and fish products), vegetables, fruits and some traditional export commodities like tea and coffee (Table 2).

In the total export of US\$ 30 billion in 2012-13, the major items of export were cotton (17.3\%), cereals (16.4\%), fish and marine products $(7.6 \%)$ and meat (6.9\%). Notwithstanding the decline in share of some commodities, all the commodity groups have registered significant positive growth rates. One notable commodity has been meat and meat products which have registered a growth rate of $27.6 \%$ with a low instability at $4.8 \%$. This was mainly due to the growth in export of buffalo meat which account for close to $80 \%$ of total meat exported. Another significant sector is marine fish and fish products which has registered a growth rate of $8 \% /$ year. The marine products' export is facing a slowdown in recent periods, mainly on account of reduced demand in European and United States market. Further, there has been stagnation in marine fish production in recent years. Other significant commodity groups in terms of growth performance are spices and cereals. Among non-food crops, cotton and natural gums/resins have registered significant export growth. Cotton has traditionally contributed to Indian foreign exchange earning through textile export. Such a raise in export contributed by productivity improvement through research and development activities (Rajendran et al. 2005). In case of cotton, the production advantage brought about by $\mathrm{Bt}$ cotton technology helped India to achieve higher export levels. The highest export growth is in guargum, mainly on 
An overview of export performance of agricultural products in India

Table -1 Compositional changes in India's agricultural exports, 2003-04 to 2012-13(TE average)

\begin{tabular}{|l|l|l|l|l|l|l|}
\hline Item & Value (US \$ million) & Share (\%) & Growth (\%) & Instability(\%) \\
\hline & & & & & \\
\hline & $2003-2004$ & $2012-2013$ & $2003-2004$ & $2012-2013$ & & \\
\hline & & & & & & \\
\hline Meat and offals & 299.1 & 2720.4 & 3.3 & 6.9 & 27.6 & 4.8 \\
\hline Fish and marine products & 1283.8 & 2976.7 & 14.0 & 7.6 & 8.7 & 10.8 \\
\hline Vegetables and tubers & 272.7 & 981.1 & 3.0 & 2.5 & 15.2 & 6.7 \\
\hline Fruits and nuts & 554.6 & 1355.4 & 6.1 & 3.5 & 10.0 & 3.1 \\
\hline Coffee & 151.5 & 593.8 & 1.7 & 1.5 & 15.8 & 10.0 \\
\hline Tea & 337.2 & 782.6 & 3.7 & 2.0 & 10.3 & 3.9 \\
\hline Cereals & 1361.1 & 6424.8 & 14.9 & 16.4 & 16.7 & 14.9 \\
\hline Spices & 211.1 & 1286.1 & 2.3 & 3.3 & 24.1 & 10.1 \\
\hline Rice & 930.3 & 4567.0 & 10.2 & 11.6 & 17.4 & 12.6 \\
\hline Oilseeds & 325.4 & 1660.3 & 3.6 & 4.2 & 20.3 & 9.3 \\
\hline Guargum and other resins & 90.5 & 2951.5 & 1.0 & 7.5 & 41.5 & 34.6 \\
\hline Sugar & 354.7 & 1698.0 & 3.9 & 2.5 & 6.4 & 44.7 \\
\hline Raw hides and skins & 510.1 & 990.0 & 5.6 & 0.29 & 12.5 & 6.4 \\
\hline Natural rubber & 29.5 & 114.7 & 0.32 & 17.3 & 20.2 & 19.9 \\
\hline Cotton (raw and yarn) & 1293.5 & 6798.2 & 14.1 & 76.3 & 17.0 \\
\hline Total & 6834.2 & 29932.7 & 74.7 & 6.9 \\
\hline
\end{tabular}

Source: Computed by the authors using data from Ministry of Commerce, Government of India.

account of sudden rise in its demand for industrial uses. The high level of instability points to the vulnerability part of the demand. This is quite noticeable in case of sugar, in which case the export has expanded at the rate of close to $25 \%$ /year, but with a high instability of $45 \%$. This is mainly owing to the policy shifts in case of sugar, which includes restriction on its exports at times when domestic prices rise.

Table 2 Price competitiveness of exports of wheat, rice, maize and potato exported from India

\begin{tabular}{|c|c|c|c|c|c|c|c|}
\hline \multicolumn{2}{|l|}{ Wheat } & \multicolumn{2}{|l|}{ Rice } & \multirow{2}{*}{$\begin{array}{r}\text { Maize } \\
\text { Country }\end{array}$} & & \multicolumn{2}{|l|}{ Potato } \\
\hline Country & Ratio & Country & Ratio & & & Country & Ratio \\
\hline Argentina & 0.77 & Bangladesh & 0.91 & Argentina & 0.73 & Belgium & 1.47 \\
\hline Australia & 1.32 & Brazil & 1.09 & Brazil & 1.12 & China & 1.15 \\
\hline Canada & 1.10 & China & 1.63 & India & 1.00 & Egypt & 1.14 \\
\hline Chile & 1.75 & India & 1.00 & Ukraine & 0.71 & France & 2.16 \\
\hline China & 0.96 & Indonesia & 1.07 & USA & 0.83 & Germany & 2.30 \\
\hline France & 0.86 & Pakistan & 1.12 & & & India & 1.00 \\
\hline Germany & 1.10 & Philippines & 1.39 & & & Israel & 3.10 \\
\hline India & 1.00 & Thailand & 0.89 & & & Netherlands & 1.50 \\
\hline Pakistan & 0.65 & Bangladesh & 0.91 & & & Pakistan & 1.38 \\
\hline Russia & 0.83 & & & & & & \\
\hline
\end{tabular}

The ratio of producer prices with respect to that of India in the latest available years. Source: Computed by the authors using data from FAO.

Where total production has stagnated. One notable feature is that Asian countries are gradually emerging as the major competitors for Indian exports, notably in case of plantation crops. For example, in terms of producer prices, Sri Lanka is a competitor of India in case of tea; Thailand in case of sugarcane; Malaysia, Sri Lanka and Thailand in case of natural rubber and Vietnam in case of black pepper. This is on account of stagnation in productivity of the crops. Another contributing factor might be the lack of private capital formation in plantation sector. Agricultural price movements in India are mainly influenced by international prices rather than output fluctuations (Sekhar 2003). Many commodities produced in tropical regions have low demandsupply elasticities. Therefore, even small changes in prices may lead to volatility in prices (Kuruvila et al. 2012). There seems to be a high level of instability in prices of plantation crops. The instability of prices dissuades farmers from undertaking long term investments in agriculture, compromising long-term sustainability.

The production of rice and wheat also expanded at an annual rate of 2.0 and $2.7 \%$, respectively. The growth in production in rice has entirely been contributed by yield expansion whereas that in case of wheat was contributed by both area and yield improvement. In case of rice, large scale transition of area from non-basmati to basmati is noticed in Haryana and Punjab. However, the domestic price of basmati rice is highly dependent on international prices. The ban on the exports of non-basmati rice while permitting the export of basmati rice in the recent past might also have contributed to expansion of area under basmati rice. Deceleration of TFP might

DOI: $10.9790 / 487 X-1902010105 \quad$ www.iosrjournals.org $3 \mid$ Page


have contributed to the stagnation of yield growth in case of wheat (Bhushan 2005), while in case of rice it might be due to the reduced input intensification despite a catching up of the TFP by low productivity states in recent periods (Suresh 2013).

India imports close to $14 \%$ of the total requirement of pulses. Chickpea and pigeonpea are the major pulses consumed in India. There is a glaring difference in the growth performance of these crops. The growth in production of chickpea has been at the rate of 5.9\%/year-contributed by $4 \%$ growth in the area and rest by yield. Pigeon pea expanded its production at the rate of $1.9 \%$ contributed largely by the expansion of area (at the rate of $0.7 \% /$ year). Chand et al. (2011) has noted, contrasting performance of TFP growth in case of both chickpea and pigeonpea, during the period of 1970-2005, characterised by an improvement in the case of former and a moderation in case of the latter.

India meets close to half of the domestic requirement of oilseeds through imports. In 2012, India imported vegetable oils worth US \$ 97.9 million. Of India's production of 29.8 million tonnes of edible oil in 2012 , more than $80 \%$ of production is contributed by three crops, viz. soybean (40.8\%), groundnut $(23.4 \%)$ and rapeseed/mustard (22.1\%) (DES 2014). During the past decade, yield of oilseeds have depicted positive trends, ranging from $0.46 \%$ in sunflower and $9.08 \%$ in soybean. Oilseeds in general have experienced a stagnation/deceleration of TFP growth for a long period of time (Chandel 2007, Chand et al. 2011). It is forecasted that given high income elasticity of demand, and improvement of the per capita income, the total demand for edible oils by 2030 would be to the tune of 25 million tonnes. There were some concerted efforts to improve the domestic oilseeds production, with the initiative of Technology Mission on Oilseeds and later with the inclusion of oil palm under the ambit of the programme. However, at current level of yield growth and area expansion, India will not be able to meet the domestic requirement without imports.

The major spices exported from India are chillies, coriander, pepper and cardamom. There was a clear difference in the trends in productivity of these crops. Chillies and coriander have depicted positive growth, while cardamom and pepper show negative growth. However, positive growth trend in area was noted only in case of coriander. In view of the stagnation of yields and the high level of completion from other countries, notably Vietnam, India is likely to see a weakening of export prospects in future too.

Fruits in general have exhibited an improvement in production with some exceptions. Amongst five fruits under consideration, only banana has shown robust growth rates in yield, while all others exhibited positive trend growth in area under cultivation. In case of grapes the statistically significant negative yield growth would be a limiting factor in boosting its exports. Another crop of high level of export prospects is pomegranate but its share in the total export is very low. The development of superior quality of pomegranate varieties and pacagae of practice has helped to boost its production, notably from rain fed regions. This would in future, contribute to boosting the export. Going by export shares the most important fruits exported from India is Mango. The area under mango has depicted significant growth in the past decade. However, slow growth in productivity is a concern for the crop Among the nuts, cashew is the most important one, exported from India. However, India's export of cashew kernel is dependent on the large scale import of raw cashew nuts (in shell) Imported mainly from African countries.

Productivity stagnation at national level continues to be an impediment in its export performance.All the vegetable crops considered have registered significant growth in production,however productive has been growing significantly only in case of onion, tomato and cauliflower. The onion production has grown at the rate of about $14.4 \%$ per year, triggered by expansion of both area and productivity improvement. The production frowth at the rate of about $5.4 \%$ in potato was contributed mainly by area expansion $(4.8 \%)$ with no prominent impacts of productivity growth. There are improved varieties suitable for processing and export. However, India's ability to improve production of quality potatoes depend on improving the value chain in terms of higher share of benifits to the farmers and development of institutional initiatives like contract farming.

\section{Conclusion And Implications}

The present study has anaylysed the trend in exports of agricultural commodities from India during the past decade and examined the prospects of boosting it. The study finds that there was significant improvement in the export of agricultural commodities, but this was characterised by a shift in commodity composition. This would implication on the area allocation for crops, crop diversification and farm income. Significant increase in the share in total export has been noted in case of cereals, guargum, cotton, spices, and sugar. On the other hand, the share has declined in some commodities, fish and marine products, fruits and nuts, coffee and Tea. Among the major commodity groups high growth rates were registered by basmati rice and maize in case of cereals, chillies and coriander among spices, mango and grapes among fruits. And onion and potato among vegetables. Consistent growth with low instability was noted in case of meat and meat products and spices. Some commodities with high growth is depicting high instability ss well, as seen in guargum and other resins, sugar and cotton. The high instability carries a risk of falling market prices, and is a concern for assuring farm income to the farmers and for linking them with markets. 
The comparative advantage improved in case of cotton, maize, and certain fruits and vegetables over time, but declined in case of some plantation crops, rice and wheat. In case of plantation based spices and other commodities, India is gradually losing its comparative edge, mainly to Asian countries. Improving the comparative advantage in export warrants generation of exportable surplus and internationally competent prices. There was wide variation in the growth in yield of various crops and crop groups. Yield improvements through changes in TFP would be a potential factor that would determine India's ability to generate exportable surplus, comparative advantage and export growth.

\section{Implications}

- The Indian government will have to evolve a comprehensive long term strategy, which can be formulated only on the basis of an extensive study of consumer preferences in terms of style, colour, design etc.

- There is an urgent need for the technological upgradation of export industries.

- There is an urgent need for the improvement in the quality of product, standards and packaging.

- There has been emerged an urgent need of promoting diversification of agriculture.

- Indian government should provide special incentives for the gems and jewellery sector.

- There should be given more incentives in the specialization of handloom goods, improve market access information.

\section{References}

[1]. Irwin, D.A., and M. Tervio (2002), "Evidence from the Twentieth Century”, Journal of International Economics, Vol. 58 (1), pp. $1-18$.

[2]. Balassa, Bela. (1978), "Exports and economic growth: Further evidence", Journal of Development Economics, Vol. 5 (2), p. 181189.

[3]. Feder, G. (1983), “On Exports and Economic Growth”, Journal of Development Economics, Vol. 12 (1/2), p. 59-73.

[4]. Kavoussi, R.M. (1984), "Export Expansion and Economic Growth: Some Further Empirical Evidence", Journal of Development Economics, Vol. 14 (1-2), p. 241-50.

[5]. Kravis, I.B. (1970), "Trade as Handmaiden of Growth: Similarities between the Nineteenth and Twentieth Centuries", Economic Journal, Vol. 80 (320), p. 850-72.

[6]. Nurkse. R. (1962), "Patterns of Trade and Development", Wicksell Lectures 1959, Oxford

[7]. Tyler, W. (1981), "Growth and export expansion in developing countries: Some empirical evidence", Journal of Development Economics, Vol. 9 (3), p. 121-130.

[8]. Sen, A K. (1962), “An Aspect of Indian Agriculture”, The Economic Weekly, Vol. 14 (4-6), pp. 243-46.

[9]. Anonymous (2005), "Cashew Statistics", Cashew Bulletin, Vol. 43(3) (13-17).

[10]. Arvind, K. (2000), "Performance of India's Rice Export” M.Sc. (Agri) Thesis, University of Agricultural Sciences, Bangalore.

[11]. Ashalatha (2000), "Export Trade Performance of Indian Cashew" M.Sc. (Agri.) Thesis,

[12]. University of Agricultural Sciences, Bangalore.

[13]. Balasubramanian, P.P. and Singh, H.P. (2002), "Global Cashew Production and Trade

[14]. Vis-à-vis India's Participation”, Indian Cashew Issues and Strategies, p.17-30.

[15]. Behura, D. and naik, D. (1997), "Growth of Cashew Production in India with Special Reference to its Export Opportunities" Indian Journal of Agricultural Marketing, Vol. 11 (1\&2), p.31.

[16]. Hegde, I.N. (1998), "Foreign Trade in India's Economic Growth - A Quantitative Analysis" Ph.D. Thesis, Karnataka University, Dharwad.

[17]. Nageshwara M R and S Srinivas Rao (2009), "Direction of Trade in Indian Agricultural Commodity Exports", Southern Economist, Vol. 47 (19), pp.23.

[18]. Singh, Kehar \& Inder Sain (2003), "Prospects of Agricultural exports of India: A Composite Index Approach" Indian Journal of Agricultural Economics, pp. 781-799.

[19]. Goldar Biswanath (1989), "Determinants of India's export performance in engineering products (www)"Developing economies. Available from http://202.244.105.129/English/Publish/Periodicals/De/pdf/89_01_01.pdf.

[20]. Findlay and Ronald (1985), "Primary export, manufacturing, and development", The Primary Sector and Economic Development, London, Croom Helm, pp. 218-33.

[21]. Tilton, John E. (2003), "Creating wealth and competitiveness in mining", Mining Engineering.

[22]. www.tradingeconomics.com/india/exports

[23]. www.wto.org/english/res_e/statis_e/its2011_e/its11_toc_e.htm 